\title{
Prevalence of helicobacter pylori in diabetes patients and health workers at a tertiary hospital in south west Nigeria.
}

\author{
*Adeleye O.O. ${ }^{1}$, Odusan O.A. ${ }^{1}$, Ale A.O. ${ }^{1}$, Oyelekan A.A. ${ }^{2}$, Afe O.T. ${ }^{1}$, Olaitan A.O. ${ }^{1}$
}

\begin{abstract}
Objective: Helicobacter Pylori (H.P) is a common bacterial infection that has been associated with diabetes mellitus (DM). The aim of the study was to determine the prevalence of Helicobacter pylori infection in patients with DM and the association with anthropometry, duration of DM and medication.
\end{abstract}

Method: A cross sectional study involving consecutive recruitment of 193 subjects; 99 diabetics attending the outpatient clinic and 94 controls from hospital staffs. The Heliprobe urea breath test was used in the detection of H.P.

Results: The prevalence of H.P was $96.8 \%$ in the controls and $85.6 \%$ in the diabetics $\left(\mathrm{X}^{2}=7.56, \mathrm{P}=0.006\right)$ with significant female preponderance among the diabetics $\left(\mathrm{X}^{2}=7.01, \mathrm{P}=0.008\right)$. H.P had no significant association among the diabetics with regards to BMI, duration of DM and medication.

Conclusion: The prevalence of Helicobacter pylori was higher in the control than the diabetics.

Keywords: Helicobacter pylori, diabetes mellitus, tertiary hospital

\author{
* Correspondence author \\ Dr Adeleye O.O. \\ http://orcid.org/0000-0001-6069-5850 \\ Email: funtos2000@yahoo.co.uk.
}

${ }^{1}$ Department of Medicine, Olabisi Onabanjo University Teaching Hospital, Sagamu, Nigeria.

${ }^{2}$ Department of Surgery, Olabisi Onabanjo University Teaching Hospital, Sagamu, Nigeria.

Research Journal of Health Sciences subscribed to terms and conditions of Open Access publication. Articles are distributed under the terms of Creative Commons Licence (CC BY-NC-ND 4.0). (http://creativecommons.org/licences/by-nc-nd/4.0).

http://dx.doi.org/10.4314/rejhs.v7i2.11 


\title{
Prévalence de Helicobacter pylori chez des patients diabétiques dans un hôpital tertiaire du sud-ouest du Nigéria.
}

\author{
*Adeleye O.O. ${ }^{1}$, Odusan O.A. ${ }^{1}$, Ale A.O. ${ }^{1}$, Oyelekan A.A. ${ }^{2}$, Afe O.T. ${ }^{1}$, Olaitan A.O.
}

\begin{abstract}
Resume
Objectif: Helicobacter Pylori (H.P) est une infection bactérienne commune associée au diabète sucré. Le but de cette étude était de déterminer la prévalence de l'infection à Helicobacter pylori chez les patients atteints de diabète et l'association avec l'anthropométrie, la durée du diabète et la médication.
\end{abstract}

Méthode: Une étude transversale impliquant le recrutement consécutif de 193 sujets; 99 diabétiques fréquentant la clinique externe et 94 témoins du personnel hospitalier. Le test respiratoire à l'urée Heliprobe a été utilisé pour la détection de l'HP.

Résultats: La prévalence de l'HP était de 96,8\% chez les témoins et de $85,6 \%$ chez les diabétiques $\left(\mathrm{X}^{2}=7,56, \mathrm{P}=0,006\right)$ avec une prépondérance féminine importante chez les diabétiques $\left(\mathrm{X}^{2}=7,01, \mathrm{P}=0,008\right)$. H.P n'avait pas d'association significative parmi les diabétiques en ce qui concerne l'IMC, la durée du diabète et les médicaments.

Conclusion: la prévalence d'Helicobacter pylori était plus élevée chez les témoins que chez les diabétiques.

Mots clés: Helicobacter pylori, diabète sucré, hôpital tertiaire

\footnotetext{
*Correspondence author

Dr Adeleye O.O.

http://orcid.org/0000-0001-6069-5850

Email: funtos2000@yahoo.co.uk.

${ }^{1}$ Department of Medicine, Olabisi Onabanjo University Teaching Hospital, Sagamu, Nigeria.

${ }^{2}$ Department of Surgery, Olabisi Onabanjo University Teaching Hospital, Sagamu, Nigeria.
} 


\section{INTRODUCTION}

Helicobacter Pylori (H. Pylori) is a common bacterial infection and has been recognized as a worldwide public health problem. Over $50 \%$ of the world's populations have been infected with the bacteria and the developing countries having the highest prevalence rate (1). It is the cause of several gastrointestinal diseases and non-gastrointestinal complication. Type 2 Diabetes mellitus is an emerging pandemic responsible for an estimated 3.8 million adult deaths worldwide (2). There is growing evidence to suggest that H. Pylori may play a role in diabetes as H. Pylori infection has been associated with increased levels of $\mathrm{C}$ reactive protein (CRP) and interleukin 6 (IL 6)and subsequently insulin resistance which has been epidemiologically linked to type 2 diabetes mellitus (3). Diabetes mellitus makes a patient more susceptible to infection and gastroparesis diabeticorum which may lead to bacterial overgrowth in the upper gastrointestinal tract (4). Also infection with Helicobacter pylori induces gastric inflammation leading to increase in cytokines, which could be deleterious for the control of the blood glucose in diabetics.(4). The prevalence of Helicobacter pylori colonization among diabetics as reported in world literature varies between $37 \%$ and $85 \%$. $(5,6)$. Although the findings of various studies are inconsistent, the presence of $H$. pylori is found to be higher in diabetic patients compared with non-diabetic patients (7-9). There is paucity of data on $\mathrm{H}$. Pylori in Diabetes mellitus in Nigeria hence the need for this study. This study determined the prevalence rate of H. Pylori in patients with Type 2 Diabetes Mellitus as against non-diabetics and any association with relevant clinical parameters.

\section{MATERIALS AND METHODS Study design}

This was a cross-sectional study in which patients with type 2 Diabetes attending the Endocrine and metabolic clinic of the Olabisi Onabanjo University Teaching Hospital were consecutively recruited; similarly age and sex matched healthy consenting controls were also recruited consecutively among the hospital workers. Helicobacter pylori screening was done using the urea breath test. The sample size was calculated using the Cochran's formula $\mathrm{N}=$ $\mathrm{Z}^{2} \mathrm{pq} / \mathrm{d}^{2}$ where $\mathrm{Z}=$ Standard normal deviate set at $1.96, p=$ set at $13 \%, q=(1-p) d=$ is the acceptable margin of error set at 0.05 . This gave a Sample size of 173 , attrition of twenty was added and sample size became 193.
Hospital setting: Olabisi Onabanjo University Teaching Hospital is 205 bedded hospitals situated in Ogun State (Sagamu). She is located in the south western part of Nigeria and receives referrals from both public and private hospitals from Lagos metropolitan and the communities around Sagamu for both inpatient and outpatient care.

\section{Procedure}

This single point study involved consenting consecutive Type 2 DM patients and similar age and sex matched healthy controls. The inclusion criteria for the controls was for their fasting blood drawn to meet the WHO criteria of FBG $<7.1 \mathrm{mmol} / \mathrm{L}$. For all subjects, they were excluded if there was a history of peptic ulcer disease, intake of antibiotics, proton pump inhibitors, $\mathrm{H} 2$ receptor blockers, or antacids in the last 4 weeks, past and present evidence of active gastrointestinal bleeding, jaundice and symptoms of upper astrointestinal disease such as indigestion, nausea, vomiting and epigastric burning pain. A well-structured pretested questionnaire was administered by a medical doctor to each participant. The questionnaire included bio data, anthropometry, socioeconomic variables such as occupation and level of education, prior knowledge of diabetic status, duration of diabetes and the medication they were on. The indigenous language of the people in Ogun state is Yoruba although the questionnaire was in English. When needed, translation was done. Informed consent was obtained from the patients after the purpose of the study was explained to them with anonymity assured. Screening of H. pylori status was done with the Urea breath testing (UBT) which is currently considered to be the gold standard for noninvasive diagnosis of Helicobacter pylori infection; the Heliprobe ${ }^{\circledR}$ System has been validated and found to be comparable to conventional UBT, with the advantage of being a diagnostic system for detection of $\mathrm{H}$. pylori directly in the doctor's office. Results are expressed as $0=$ patient not infected (negative), $2=$ patient infected (positive), $1=$ borderline. Ethical approval was obtained from the Ethics Committee of the Hospital before the study commenced.

Statistical package for social science (SPSS) version 20 was used for data analysis. The univariate analysis was performed by descriptive statistics through frequencies and percentages. Categorical variables were expressed as frequency (\%), and group comparison were by 
the Pearson's Chi-square. Student t test was used for Intergroup mean comparison. A $p<0.05$ was used as cut off level for statistical significance.

\section{RESULTS}

A total of 193 participants' were recruited. There were 99 (51.3\%) diabetics and 94 (48.7) non-diabetics. The mean age of all the subjects was $60.0 \pm 12.3$ years and the modal age group was 41-60years. There were predominantly female, $118(61.1 \%)$ with a female to male ratio of $1.6: 1$ Tertiary education was obtained by $33.2 \%$ of the subjects. See table 1

Helicobacter pylori was positive in 85 $(85.9 \%)$ of diabetics and $91(96.8 \%)$ of nondiabetics $\left(X^{2}=7.197, p=0.007.\right)$. The overall prevalence of Helicobacter Pylori among all the subjects was 176(91.2\%). Overall, more females, 113 (95.8\%) were positive for Helicobacter Pylori when compared with the males $(84.0 \%)$ which was statistically significant $\left(\mathrm{X}^{2}=7.899, \mathrm{p}=0.005\right)$. Among the diabetics population, more females $(93.3 \%)$ were statistically positive for $\mathrm{H}$. Pylori compared with the males $(74.4 \%)\left(X^{2}=7.009, p=0.008\right)$; whereas among the non-diabetics the difference in positivity across the gender was not significant. Helicobacter Pylori positivity across the three age groups showed a higher positivity across the age group 20-40 years in both the diabetics and non-diabetics however it was not significant. With regards to body mass index, there was no significant association across all categories as regards to positivity to H.P among both the diabetic and the non-diabetes. See Table 2 and 3. Among those positive for $\mathrm{H}$. Pylori among the diabetics, there was no statistical difference when the medications they were on were compared. The underweight diabetics appeared to be more positive for H. Pylori when compared with the other categories however it was not significant. It was also observed that there was no significant association between the presence of H.Pylori and the duration of diabetes. See Table 3

\section{DISCUSSION}

Helicobacter pylorus is a common bacterial infection which has been implicated to cause gastrointestinal and non-gastrointestinal related disorders. Patients with diabetes mellitus are susceptible to infection and gastroparesis diabeticorum which may lead to bacterial overgrowth in upper gastro-intestinal tract hence the need for this study to identify at risk group. In this study, the prevalence of Helicobacter pylorus was $96.8 \%$ in non-diabetics and $85.6 \%$ in diabetics $(p<0.05)$. This contrasts a study by Oluyemi et al in Nigeria who reported significantly lower prevalence in the diabetics and the control group of $18 \%$ and $13 \%$ respectively (10). Furthermore the findings of studies on the prevalence of H. Pylori in diabetes mellitus patients have been contradictory; some studies found that $H$. pylori infection was significantly higher in the DM group compared to the control group $(11,12)$ while some studies did not find any significant difference in the DM group and the control group with regard to $H$. pylori infections $(13,14)$. This study showed a higher prevalence of $\mathrm{H}$. Pylori in the control group. Although the finding in this study seems to be at contrast to either studies in which Helicobacter Pylori was more prevalent in diabetes than control group or showed no differences; generally the literature have reported that $\mathrm{H}$. Pylori has a high prevalence in Africa as the infection is acquired in childhood. $(15,16)$ In fact in most under developed countries an endemic of Helicobacter pylori goes unchecked and most adults are infected $(4,17)$.

Among the males and females, it was observed that the females had higher prevalence of Helicobacter Pylori in both the non- diabetics (98.3\%) and the diabetics $(93.3 \%)$ however the female preponderance was significant $(\mathrm{P}<0.05)$ among the diabetics. This apparently suggests a female predilection for the infection. Other documented studies however have showed a male preponderance in both in the diabetics and control groups $(4,18,19)$, although Shahram et al, demonstrated that the female were significantly more positive for $\mathrm{H}$. Pylori in the study done albeit among patients with gastric tumor (20). The reason for this female preponderance in this study is unclear.

In relation to age, the prevalence of the Helicobacter Pylori positivity was found to be higher among the age-group 20-40 years in both the non-diabetics $(100 \%)$ and in the diabetic group $(100 \%)$, however though there was no statistical significance when compared with the other age groups. The plausible reason might be because the infection is acquire in childhood and may persist till an older age especially if left unchecked. Among the diabetics, the prevalence of H. Pylori in underweight was higher when compared with the other categories however it was not significant which is in contrast with reported study where H.Pylori has been associated with overweight and obesity. (21) When considering the medications the diabetics 
were on and duration of diabetes in relation with H.Pylori positivity, no significant differences was observed. These findings are comparable to another study done (4).

\section{CONCLUSION}

Helicobacter pylori infection is more prevalent in non-diabetics than in diabetics and there was a female predilection in all the study population, significantly more among the diabetics. Among the diabetic population there was no significant association with body mass index, and the medication they were on.

Acknowledgement: We wish to appreciate Biofem Pharmaceuticeutical Nigeria Limited who donated the Urea breath test kits for this study.

Conflict of Interest: None to declare.

\section{REFERENCES}

1. Go MF. Review article: natural history and epidemiology of Helicobacter pylori infection. Aliment Pharmacol Ther. 2002; 16(Suppl): 3 15.

2. Van Dieren S, Beulens JW, Van Der Schouw YT,
Grobbee DE, Neal B. The global burden of diabetes and its complication: an emerging pandemic. Eur J Cardiovasc Prev Rehaabil. 2010; 17 (Suppl 1): S3-S8

3. Nabipour I, Vahdat k, Jafari SM, Pazoki R, Sanjdideh Z. The association of metabolic syndrome and Clamydia Pneumoniae, Helicobacter Pylori, Cytomegalovirus, and herpes Simplex virus type 1: The Persian Gulf Healthy Heart Study. Cardiovasc Diabetol. 2006; $5: 25$.

4. Khwaja SZ, Vidyasagar R, Manoj K. A study of Helicobacter pylori infection in diabetes mellitus. Int J Res Med Sci. 2016; 4(9):4166-4171.

5. Hurtado A, Owen RJ. A rapid identification scheme for Helicobacter pylori and other species of helicobacter based on 23 S rRNA gene polymorphism. System Appl. Microbiol. 1997; 20:222-31.

6. 6. Miah MA, Rahman MT, Hasan M, Khan AK. Sero prevalence of Helicobacter pylori among the diabetic population in Bangladesh: A comparative serological study on the newly diagnosed and older diabetics. Bangladesh Med Res Counc Bull. 2001;27(1):9-18.

7. Devrajani BR, Shah SZA, Soomro AA, Devrajani T. "Type 2 diabetes mellitus: a risk factor for Helicobacter pylori infection: a hospital based case-control study," Int J Diabetes Dev Ctries. 2010;30(1):22-26. 
Table 1: Demographic and Helicobacter Pylori positivity among the Participants.

\begin{tabular}{|c|c|c|c|c|}
\hline Variable & $\begin{array}{l}\text { Diabetic } \\
\mathrm{n}=99\end{array}$ & $\begin{array}{l}\text { Non-Diabetic } \\
\mathrm{n}=94\end{array}$ & $\mathrm{X}^{2} / \mathrm{t}$ & $\mathrm{P}$ value \\
\hline \multicolumn{5}{|l|}{ Age group } \\
\hline $20-40(n=11)$ & $4(36.4)$ & $7(63.6)$ & & \\
\hline $41-60(n=97)$ & $50(51.5)$ & $47(48.5)$ & 1.660 & 0.436 \\
\hline $61-80(n=78)$ & $44(56.4)$ & $34(43.6)$ & & \\
\hline Mean age & $60.7 \pm 12.0$ & $58.4 \pm 12.6$ & 1.281 & 0.202 \\
\hline \multicolumn{5}{|l|}{ Sex } \\
\hline Males $(n=75)$ & $39(52.0)$ & $36(48.0)$ & 0.024 & 0.876 \\
\hline Females $(n=118)$ & $60(50.8)$ & $58(49.2)$ & & \\
\hline \multicolumn{5}{|l|}{ Educational } \\
\hline \multicolumn{5}{|l|}{ Background } \\
\hline None $(n=25)$ & $16(64)$ & $9(36.0)$ & & \\
\hline Primary $(n=42)$ & $22(52.4)$ & $20(47.6)$ & 3.702 & 0.295 \\
\hline Secondary $(n=53)$ & $25(47.2)$ & $28(52.8)$ & & \\
\hline Tertiary $(n=64)$ & $27(42.2)$ & $37(57.8)$ & & \\
\hline \multicolumn{5}{|l|}{ H. Pylori } \\
\hline Positive & $85(85.9)$ & $91(96.8)$ & 7.197 & $0.007 *$ \\
\hline Negative & $14(14.1)$ & $3(3.2)$ & & \\
\hline
\end{tabular}

Table 2: Relationship between $\mathrm{H}$. pylori positivity and demographic in Non-Diabetic subjects

\begin{tabular}{|c|c|c|c|c|}
\hline Variable & $\begin{array}{l}\text { H. Pylori } \\
\text { Positive } \\
\mathrm{N}=91\end{array}$ & $\begin{array}{l}\text { H. Pylori } \\
\text { Negative } \\
\mathrm{N}=3\end{array}$ & $\mathrm{X}^{2}$ & P VALUE \\
\hline \multicolumn{5}{|l|}{ Age-group } \\
\hline $20-40(n=7)$ & $7(100.0)$ & $2(0.0)$ & & \\
\hline $41-60(n=47)$ & $46(97.9)$ & $1(21.0)$ & 1.113 & 0.573 \\
\hline $61-80(n=34)$ & $32(94.1)$ & $2(5.9)$ & & \\
\hline \multicolumn{5}{|l|}{ Gender } \\
\hline Male $(n=36)$ & $34(94.4)$ & $2(5.6)$ & 1.055 & 0.304 \\
\hline Female $(n=58)$ & $57(98.3)$ & $1(1.7)$ & & \\
\hline \multicolumn{5}{|l|}{ Body mass index } \\
\hline Underweight $(\mathrm{n}=6)$ & $6(100)$ & $0(0)$ & & \\
\hline Normal weight $(n=21)$ & $21(100)$ & $0(0)$ & 1.942 & 0.584 \\
\hline Overweight $(\mathrm{n}=28)$ & $26(92.9)$ & $2(7.1)$ & & \\
\hline Obese $(n=16)$ & $15(93.8)$ & $1(6.2)$ & & \\
\hline
\end{tabular}

Table 3: Relationship between H.Pylori positivity and demographic and clinical parameters among diabetes

\begin{tabular}{|c|c|c|c|c|}
\hline Variable & $\begin{array}{l}\text { H. Pylori } \\
\text { Positive } \\
\mathrm{n}=85\end{array}$ & $\begin{array}{l}\text { H.Positive } \\
\text { Negative } \\
n=14\end{array}$ & $\mathrm{X} 2$ & $\mathrm{P}$ value \\
\hline \multicolumn{5}{|l|}{ Age group } \\
\hline $20-40(n=4)$ & $4(100)$ & $0(0)$ & 0.765 & 0.682 \\
\hline $41-60(n=50)$ & $43(86.0)$ & $7(14.0)$ & & \\
\hline $61-90(n=44)$ & $37(84.1)$ & $7(15.9)$ & & \\
\hline \multicolumn{5}{|l|}{ Sex } \\
\hline Males $(n=39)$ & $29(74.4)$ & $10(25.6)$ & 7.009 & $0.008 *$ \\
\hline Females $(n=60)$ & $56(93.3)$ & $4(6.7)$ & & \\
\hline \multicolumn{5}{|l|}{ Medication } \\
\hline OHA $(n=62)$ & $53(85.5)$ & $9(14.5)$ & 0.169 & 0.919 \\
\hline OHA plus insulin $(n=14)$ & $12(85.7)$ & $2(14.3)$ & & \\
\hline Insulin $(n=1)$ & $1(100)$ & $0(0)$ & & \\
\hline \multicolumn{5}{|l|}{ Body mass index } \\
\hline Underweight $(\mathrm{n}=3)$ & $3(100)$ & $0(0)$ & & \\
\hline Normal weight $(n=18)$ & $13(72.2)$ & $5(27.8)$ & 2.826 & 0.419 \\
\hline Overweight $(n=17)$ & $15(88.2)$ & $2(11.8)$ & & \\
\hline Obese $(n=55)$ & $46(83.6)$ & $9(16.4)$ & & \\
\hline \multicolumn{5}{|l|}{ Duration of Diabetes } \\
\hline Less than $1 \mathrm{yr}(\mathrm{n}=8)$ & $6(75.0)$ & $2(25.0)$ & & \\
\hline $1-5$ years $(n=21)$ & $18(85.7)$ & $3(14.3)$ & 0.548 & 0.908 \\
\hline $6-10$ years $(n=14)$ & $11(78.6)$ & $3(21.4)$ & & \\
\hline$>10$ years $(n=16)$ & $13(81.2)$ & $3(18.8)$ & & \\
\hline
\end{tabular}

